\title{
Children with brain tumors: a study of nutritional status on hospital admission
}

\section{Crianças com tumores cerebrais: um estudo do estado nutricional na admissão hospitalar}

\author{
Renata Candido Tsutsumi ${ }^{1}$, Patrícia da Graça Leite Speridião ${ }^{2}$
}

\begin{abstract}
Objective: to assess the nutritional status of children with brain tumors on hospital admission and to verify whether the nutritional status varies according to the type of tumor. Methods: anthropometric data of 30 children between 2 and 10 years old, of both sexes, with brain tumors and admitted to a hospital in the city of São Paulo, Brazil, were evaluated. Secondary data collection allowed to assess and classify the Z-scores of the body mass index, percentage of adequacy of the triceptal skinfold and the arm muscle circumference, carried out between the years 2004 and 2011. Results: the frequencies of brain tumors were: $33.3 \%$ astrocytic, $40 \%$ embryonal, $10 \%$ of the seal region and $16.6 \%$ ependimals. The median age and body mass index $\mathrm{Z}$ scores were 5.5 years $(4.0$ and 7.0$)$ and 0.66 SD (- 1.41 and $0.87)$, respectively. The median percentage of adequacy of arm muscle circumference was $98 \%(88.9$ and 103.2) and the triceptal skinfold was 83.2\% (57.0 and 106.6). As for nutritional status, 21 (70\%) of the children were eutrophic; 7 (23.3\%) overweight and 2 (6.7\%) with malnutrition/wasting showing no significant difference between groups of brain tumors $(p=0.721)$. The percentages of adequacy of the triceptal skinfold and of the arm muscle circumference also showed no significant difference between the different types of brain tumors ( $p=0.865$ and $p=0.860$, respectively). Conclusion: at the time of hospital admission, the children were in good nutritional status, regardless of the type of brain tumor.
\end{abstract}

Keywords: Brain tumors. Pediatrics. Nutritional status.

\section{Resumo}

Objetivo: avaliar o estado nutricional de crianças com tumores cerebrais na admissão hospitalar e verificar se o estado nutricional varia de acordo com o tipo de tumor. Métodos: avaliou-se os dados antropométricos de 30 crianças entre 2 e 10 anos, de ambos os sexos, com tumores cerebrais e admitidas em um hospital na cidade de São Paulo, Brasil. A coleta secundária de dados permitiu avaliar e classificar os escores $Z$ do índice de massa corporal, percentual de adequação da dobra cutânea triceptal e da circunferência muscular do braço, realizados entre os anos de 2004 e 2011. Resultados: as frequências dos tumores cerebrais foram: 33,3\% astrocíticos, $40 \%$ embrionários, $10 \%$ da região selar e 16,6\% ependimais. As medianas de idade e dos escores $Z$ do índice de massa corporal

${ }^{1}$ M.Sc. in Food, Nutrition and Health from Universidade Federal de São Paulo (Unifesp), Campus Baixada Santista, Santos, São Paulo, Brazil. E-mail: renata.tsutsumi@gmail.com

${ }^{2}$ Ph.D. in Sciences from Universidade Federal de São Paulo, Campus São Paulo, São Paulo, São Paulo, Brazil. Associate Professor at the Department of Health, Education and Society at the Universidade Federal de São Paulo, Campus Baixada Santista, Santos, São Paulo, Brazil. E-mail: patricia@dominustech.net 
foram, respectivamente, 5,5 anos $(4,0$ e 7,0) e 0,66 DP (- 1,41 e 0,87). A mediana do percentual de adequação da circunferência muscular do braço foi de $98 \%(88,9$ e 103,2$)$ e da dobra cutânea triceptal foi 83,2\% (57,0 e 106,6). Quanto ao estado nutricional, 21 (70\%) das crianças apresentaramse eutróficas; 7 (23,3\%) com excesso de peso e $2(6,7 \%)$ com desnutrição/magreza, não mostrando diferença significante entre os grupos de tumores cerebrais $(\mathrm{p}=0,721)$. Os percentuais de adequação da dobra cutânea triceptal e da circunferência muscular do braço também não mostraram diferença significante entre os diferentes tipos de tumores cerebrais ( $\mathrm{p}=0,865$ e $\mathrm{p}=0,860$, respectivamente). Conclusão: no momento da admissão hospitalar as crianças se encontravam em bom estado nutricional, independentemente do tipo de tumor cerebral.

Palavras-chave: Tumores cerebrais. Pediatria. Estado nutricional.

\section{Introduction}

Cancer is the name given to a set of more than 100 different types of diseases that have in common the disorderly and malignant growth of cells that invade tissues and can manifest themselves as metastases in other regions of the body. ${ }^{(1-2)}$

The etiology of many tumors in the adult population is well described in the literature, ${ }^{(3-4)}$ however, most pediatric tumors are still classified as idiopathic due to the lack of their etiology. Considered to be a rare disease, pediatric cancer, also known as childhood and juvenile cancer (one that affects children and adolescents between 0 and 19 years old), corresponds to $1 \%$ and $3 \%$ of all malignant tumors in most populations, with brain tumors are the most common solid tumors in pediatrics. ${ }^{(1)}$ As it is a multifactorial disease, its treatment is complex and involves several aspects.

Antineoplastic treatment consists of performing, together or separately, modalities such as radiation, chemotherapy and resection surgery. The combination of these modalities is performed according to the diagnosis and stage of the disease..$^{(2,5-6)}$ These therapies often cause damage to the quality of life ${ }^{(7)}$ and, consequently, to the child's nutritional status. In the case of pediatric patients, this damage can be even more impacting. ${ }^{(7-8)}$ Thus, nutritional therapy is essential to ensure that nutritional needs are met and to prevent protein energy malnutrition during antineoplastic treatment in pediatrics. ${ }^{(4,9-12)}$ Malnutrition promotes increased hospitalization costs, reduced immune function, worsened quality of life indicators, decreased drug metabolism and, consequently, worsened overall prognosis. ${ }^{(7,13)}$
In addition to all the aspects mentioned, it is important to highlight that there is a lack of data in the literature about the etiological factors, as well as the consequences of malnutrition during the antineoplastic treatment of the different brain tumors. ${ }^{(14)}$ The better the pediatric patient's nutritional status is at the start of treatment, the better the prognosis and the quicker they will be admitted to the hospital. Thus, in view of this panorama, the present study aimed to assess the nutritional status of children with brain tumors on admission to a reference hospital for the treatment of cancer in children and adolescents in the city of São Paulo, Brazil, in addition to verify whether the nutritional status varies according to the type of tumor. The study was approved by the Research Ethics Committee of the Universidade Federal de São Paulo, $n^{\circ}$ CAAE: 42442114.4.0000.5505.

\section{Methods}

This is an observational and cross-sectional study with anthropometric data of 30 children aged between 2 and 10 years, of both genders and with brain tumors, seen at the Clinical Nutrition outpatient clinic of a cancer reference hospital children and adolescents, in the city of São Paulo, state of São Paulo, Brazil, in the period between the years 2004 and 2010.

Through secondary data collection in the records of the Clinical Nutrition outpatient clinic, anthropometric measurements ${ }^{(15-16)}$ were taken of the children. Weight and length/height were assessed based on weight/age Z scores; height/age and weight/height, with the aid of the computer 
program Anthro version 3.2.2 for children up to 5 years old, and Anthro Plus for children aged 5 years and 1 day up to 10 years. ${ }^{(17)}$ To classify the nutritional status the $\mathrm{Z}$ scores of the body mass index (BMI Z) were used according to the World Health Organization (WHO). ${ }^{(18)}$

The triceptal skinfold thickness and the arm muscle circumference were interpreted according to the percentage of adequacy in relation to the values found in percentiles 5, 25, 50, 75 and 95. ${ }^{(16)}$ When the percentage of adequacy of TST and $\mathrm{AMC}$ were below $70 \%$, the nutritional status was classified as severe malnutrition; between 70 and $80 \%$ moderate malnutrition; between 80 and $90 \%$ mild malnutrition; above 90 to $110 \%$ normal weight, between 110 and $120 \%$ overweight and, above $120 \%$ fitness, obesity. ${ }^{(19)}$

Descriptive statistics was based on absolute / relative and median frequency (p25 and p75). Anova was used to verify the variation of anthropometric indicators according to the type of tumor. Sigma Stat software was used and the level of rejection of the null hypothesis was fixed at $\leq 0.05$ or $5 \%$.

\section{Results}

Age varied between 2 and 10 years, with a median of 5.5 years $(4.0$ and 7.0$)$. As for genders $56.6 \%$ (17) were male and $43.3 \%$ (13) female (Table 1).

Table 1 - Median (p25 and p75) of age, absolute and relative frequency of the genders of children with brain tumors on hospital admission.

\begin{tabular}{lc}
\hline & Admission (N = 30) \\
\hline Age (years) & 5.5 \\
Male & $(4.07 .0)$ \\
Female & $17(56.6 \%)$ \\
\hline
\end{tabular}

Source: Authors

The frequencies of brain tumors showed that 10 children were carriers of astrocytic tumors (AT), 12 of embryonal tumors (EMT), 3 of tumors of the seal region (SRT) and, 5 of ependymal tumors (EPT), as highlighted in Table 2.

Table 2 - Absolute and relative frequency of children's with brain tumors on hospital admission.

\begin{tabular}{lc}
\hline & Admission $\mathbf{( N = 3 0 )}$ \\
\hline Astrocytic tumors & $10(33.3 \%)$ \\
Embryonal tumors & $12(40 \%)$ \\
Seal region tumors & $3(10 \%)$ \\
Ependymal tumors & $5(16.6 \%)$ \\
\hline
\end{tabular}

Source: Authors

The median of the BMI $\mathrm{Z}$ scores of all children at admission was - 0.66 (-1.41 and 0.87), while the percentage of adequacy of the triceptal skinfold thickness was $83.2 \%$ (57.0 and 106.6).
As for the arm muscle circumference, the median percentage of adequacy was $98.0 \%$ (88.9 and 103.2) as shown in Table 3. 
Table 3 - Medians (p25 and p75) of the BMI Z scores, the percentage of adequacy of the triceptal skinfold thickness and the arm muscle circumference of the children with brain tumors on hospital admission.

\begin{tabular}{|c|c|c|}
\hline & Admissi & $\mathbf{N}=\mathbf{3 0})$ \\
\hline \multirow[t]{2}{*}{ BMI Z scores (SD) } & \multicolumn{2}{|c|}{-0.66} \\
\hline & $(-1.41$ & $0.87)$ \\
\hline \multirow[t]{2}{*}{$\%$ Triceps skinfold thickness adequacy } & \multicolumn{2}{|c|}{83.2} \\
\hline & $(57.0$ & 106.6) \\
\hline \multirow[t]{2}{*}{$\%$ Arm muscle circumference adequacy } & \multicolumn{2}{|c|}{98.0} \\
\hline & $(88.9$ & 103.2) \\
\hline
\end{tabular}

Source: Authors

Table 4 shows the absolute and relative admission, 21 (70\%) of them were eutrophic; frequency of classification of children's nutritional $7(23.3 \%)$ were overweight and $2(6.7 \%)$ were status in relation to BMI. At the time of hospital malnourished/wasting.

Table 4 - Absolute and relative frequency of eutrophy, malnutrition/underweight and overweight of children with admission brain tumors on hospital.

\begin{tabular}{lc}
\hline & Admission (N $=\mathbf{3 0})$ \\
\hline Malnutrition/underweigth & $2(6.7 \%)$ \\
Eutrophy & $21(70 \%)$ \\
Overweight & $7(23.3 \%)$ \\
\hline
\end{tabular}

Source: Authors

The statistical analysis of the variation of the BMI Z scores and the percentages of adequacy of the triceptal skinfold and of the muscular circumference of the arm according to the types of brain tumors is presented in Table 5. Anova did not show statistically significant differences in the nutritional status according to the types of tumors, respectively $\mathrm{p}=0.721 ; \mathrm{p}=0.865$ and $\mathrm{p}=0.860$.

Table 5 - BMI Z scores and the percentages of adequacy of the triceptal skinfold and arm muscle circumference according to the types of brain tumors on hospital admission.

\begin{tabular}{lccccc}
\hline & $\begin{array}{c}\text { Astrocytic } \\
\text { tumors }\end{array}$ & $\begin{array}{c}\text { Embryonic } \\
\text { tumors }\end{array}$ & $\begin{array}{c}\text { Seal region } \\
\text { tumors }\end{array}$ & $\begin{array}{c}\text { Ependymal } \\
\text { tumors }\end{array}$ & p \\
\hline BMI Z scores (SD) & -0.95 & -0.14 & -0.16 & -1.06 & $0,721^{*}$ \\
& $(-1.411 .47)$ & $(-1.890 .12)$ & $(-0.351 .72)$ & $(-1.450 .27)$ & \\
$\begin{array}{l}\text { \% Triceps skinfold thickness } \\
\text { adequacy }\end{array}$ & $82.2 \pm 38.9$ & $80.1 \pm 18.9$ & $96.2 \pm 23.9$ & $83.6 \pm 30.1$ & $0.865 \#$ \\
$\begin{array}{l}\text { \% Arm muscle circumference } \\
\text { adequacy }\end{array}$ & $99.8 \pm 19.3$ & $96.6 \pm 12.3$ & $97.6 \pm 8.1$ & $92.7 \pm 14.5$ & $0.860 \#$ \\
\hline
\end{tabular}

*Kruskal-Wallis. \#One Way Analysis of Variance.

Source: Authors 


\section{Discussion}

Anthropometric data allowed an overview of the children's nutritional status at the time of admission, as well as a previous analysis of the nutritional prognosis. Thus, this study highlights positive aspects of great relevance, as it contributes to the establishment of nutritional conducts appropriate to the type of tumor, in addition to warning that the presence of malnutrition or even overweight, in the initial moments of treatment, may interfere with the course of treatment, increasing hospitalization costs, decreasing immune function, interfering with the metabolization of drugs and negatively impacting quality of life indicators..$^{(7,13)}$

Emphasis should also be given to the age of the children, which was important in the constitution of the study population, allowing the anthropometric variables of both genders to be assessed together, thus reducing the possibility of interference by puberty factors. However, the determination of the presence of brain tumors probably contributed to the small sample size of the studied population.

Still there are few studies that evaluated the nutritional status of children with cancer, and the literature highlights malnutrition as an important factor in the poor prognosis of the disease, increasing the risk of morbidity and mortality and negatively impacting the course of treatment. ${ }^{(20-23)}$ A study carried out in Morocco showed a 33\% prevalence of malnutrition in children and adolescents with solid tumors and hematological neoplasms 30. Brinksma et al..$^{(24)}$ and Tazi et al. ${ }^{(25)}$ also found malnutrition in children and adolescents with cancer, however, the prevalence was around $10 \%$. However, these results are different from those found in our study, considering that the presence of malnutrition / thinness showed a prevalence of less than $10 \%$. However, it is important to note that in these studies the study population included children and adolescents with different types of neoplasms and, our sample included exclusively children with tumors of the central nervous system. It is possible to suggest that this aspect may justify the lower prevalence of malnutrition found by us when compared to other studies.

Regarding solid tumors Garófolo et al. ${ }^{(26)}$ evaluated 44 children and found a $27 \%$ prevalence of malnutrition during the first month of treatment. In this study, the evaluated population also had brain tumor as well as our sample, however, the period of time elapsed from the moment of admission to treatment and the moment of nutritional assessment, as well as, the side effects of treatment may have negatively impacted the evolution of the nutritional status of that study population. Our study population was assessed using anthropometric parameters on hospital admission, when it was not yet under the antioneoplastic treatment protocol.

Another not less important aspect refers to the methodology used to measure anthropometric parameters, which is highlighted in the literature. ${ }^{(23,24-28)}$ Some studies have used triceptal skinfold thickness, arm muscle circumference and body mass index (BMI) to assess the nutritional status of pediatric cancer patients, the latter being widely used. However, skin folds are more sensitive in detecting changes in body composition. ${ }^{(24,27,29)}$ In this context, our results revealed that the triceptal skinfold thickness of children with brain tumors aged 2 to 10 years, showed a homogeneous percentage of adequacy, however, already indicating depletion of body fat stores.

Just as the thickness of the triceptal skinfold can reflect the composition of body fat, the arm muscle circumference reflects lean mass or the conditions of muscle mass. Our results on the percentage of adequacy of the arm muscle circumference showed medians compatible with the eutrophic standard, however, the values referring to the 25 th percentile of the arm muscle circumference of the children, showed a reduction in muscle mass. However, the results of the analysis test of the variance of the BMI Z scores and the percentages of adequacy of the triceptal skinfold and arm muscle circumference, did not show any difference in relation to the type of brain tumor. This is possibly a limitation of our study, given the sample size. 
Even so, our study showed results from a population that is usually quite adherent to the treatment as a whole, which could, among other factors, provide better maintenance of nutritional status. This aspect can also justify the presence of excess weight in almost $1 / 4$ of the evaluated population.

Thus, it can be concluded that according to the anthropometric parameters evaluated according to the types of brain tumors, at the time of hospital admission, children have good nutritional status, however, there is a need to monitor muscle and fat reserves in order to avoid malnutrition.

\section{Conflict of interest}

No conflict of interest.

\section{References}

1 Instituto Nacional de Câncer - INCA. Estimativa 2014: incidência de câncer no Brasil [Internet]. Rio de Janeiro: INCA; 2019 [citado 2020 jun 15]. Disponível em: https://www.inca.gov.br/ sites/ufu.sti.inca.local/files/media/document/ estimativa-2020-incidencia-de-cancer-nobrasil.pdf

2 Louis DN, Ohgaki H, Wiestler OD, Cavenee WK, Burger PC, Jouvet A, et al. The 2007 WHO classification of tumours of the central nervous system. Acta Neuropathol [Internet]. 2007 [cited 2018 febr 16]; 114(2):97-109. Available from: https://pubmed.ncbi.nlm.nih.gov/17618441/ doi: 10.1007/s00401-007-0243-4.

3 American Cancer Society. Cancer facts \& figures 2017. [Internet]. Atlanta: American Cancer Society; 2017 [cited 2018 july 24]. Available from: https://www.cancer.org/content/dam/ cancer-org/research/cancer-facts-and-statistics/ annual-cancer-facts-and-figures/2017/cancerfacts-and-figures-2017.pdf

4 Instituto Nacional de Câncer - INCA. Consenso Nacional de Nutrição Oncológica [Internet]. 2a ed. Rio de Janeiro: INCA; 2016 [citado 2020 jun 26]. Disponível em: https://www.inca. gov.br/sites/ufu.sti.inca.local/files//media/ document//consenso-nutricao-oncologica-volii-2-ed-2016.pdf

5 Knab B, Connell PP. Radiotherapy for pediatric brain tumors: when and how. Expert Rev Anticancer Ther [Internet]. 2007 [cited 2019 febr 16]; 7 (12 Suppl):S69-S77. Available from: https://www.tandfonline.com/.doi/ $\mathrm{abs} / 10.1586 / 14737140.7 .12 \mathrm{~s}$. S69

6 Agrawal A. Emergency approaches to neurosurgical conditions [Internet]. Houston, Texas: Springer Editora; 2014. [cited 2015 mar 4]. Available from: http://www.springer.com/us/ book/9783319106922\#aboutAuthors

7 Grant M, Kravits K. Symptoms and their impact on nutrition. Semin Oncol Nurs [Internet]. 2000 [cited 2018 sep 19]; 16(2):11321. Available from: https://pubmed.ncbi.nlm. nih.gov/10842780/ doi: 10.1053/on.2000.5738

8 Garófolo A. Diretrizes para terapia nutricional em crianças com câncer em situação crítica. Rev Nutr [Internet]. 2005 [citado 2018 set 19]; 18(4):513-27. Disponível em: https://www. researchgate.net/publication/250040872 Diretrizes_para_terapia_nutricional_em_ criancas_com_cancer_em_situacao_critica. doi: 10.1590/S1415-52732005000400007.

9 Maia PS, Tsutsumi RC, Pedro BMO, Garófolo A, Petrilli AS, Lopez FA. Nutritional supplementation in pediatric patients with cancer. Rev Soc Bras Aliment Nutr [Internet]. 2010 [cited 2019 feb 24]; 35(1). Available from: https://pdfs.semanticscholar.org/cc83/ d73f64cd4491e4546046f1c32a7fb5aad91b. pdf

10 Bozzetti F, Arends J, Lundholm K, Micklewright A, Zurcher G, Muscaritoli M. ESPEN Guidelines on Parenteral Nutrition: Non-surgical oncology. Clin Nutr [Internet]. 2009 [cited 2019 feb 24]; 28(4):44554. Available from: https://pubmed.ncbi.nlm. nih.gov/19477052/. doi: 10.1016/j.clnu.2009. 04.011 .

11 Brinksma A, Huizinga G, Sulkers E, Kamps W, Roodbol P, Tissing W. Malnutrition in 
childhood cancer patients: a review on its prevalence and possible causes. Crit Rev Oncol Hematol [Internet]. 2012 [cited 2018 apr 24]; 83(2):249-75. Available from: https:// europepmc.org/article/med/22264939. doi: 10.1016/j.critrevonc.2011.12.003.

12 Huhmann MB, August DA. Review of American society for parenteral and enteral nutrition (A.S.P.E.N.) clinical guidelines for nutrition support in cancer patients: nutrition screening and assessment. Nutr Clin Pract [Internet]. 2008 [cited 2015 feb 24]; 23(2):182-8. Available from: https:// pubmed.ncbi.nlm.nih.gov/18390787/. doi: $10.1177 / 0884533608314530$

13 Instituto Nacional de Câncer - INCA. Consenso Nacional de Nutrição Oncológica. [Internet]. Rio de Janeiro: INCA; 2009 [citado 2019 fev 11]. Disponível em: http://bvsms.saude.gov.br/ bvs/publicacoes/consenso_nacional_nutricao_ oncologico.pdf

14 Bauer J, Jürgens H, Frühald MC. Important aspects of nutrition in children with cancer. Adv Nutr [Internet]. 2011 [cited 2018 apr 24]; 2(2):67-77. Available from: https://www.ncbi. nlm.nih.gov/pmc/articles/PMC3065754/. doi: 10.3945/an.110.000141.

15 Instituto Nacional de Câncer - INCA. Consenso nacional de nutrição oncológica: paciente pediátrico oncológico [Internet]. Rio de Janeiro: INCA; 2014. [citado 2019 ago 2]. Disponível em: http://www1.inca.gov.br/ inca/Arquivos/comunicacao/Consenso_de Nutricao_Oncologica_Pediatria_PDF_final. pdf

16 Frisancho AR. Triceps skin fold and upper arm muscle size norms for assessment of nutrition status. Am. J. Clin. Nutr [Internet]. 1974 [cited 2018 aug 2]; 27(10):1052-8. Available from: https://pubmed.ncbi.nlm.nih.gov/4419774/. doi: 10.1093/ajcn/27.8.1052.

17 Frisancho AR. Anthropometric Standards for the assessment of growth and nutritional status. Ann Arbor: The University of Michigan Press; 1993.
18 Onis M, Onyango AW, Borghi E, Siyam A, Chizuru N, Jonathan S. Development of a WHO growth reference for school-aged children and adolescents. Bull World Health Organ [Internet]. 2007 [cited 2018 apr 13]; 85(9):660-7. Available from: http://www.who. int/growthref/growthref_who_bull.pdf?ua=1. doi: 10.2471/BLT.07.043497.

19 World Health Organization. Application tools. [Internet]. Geneva: World Health Organization; 2006 [cited 2018 mar 3]. Available from: http:// www.who.int/growthref/tools/en/

20 Kaatsch P. Epidemiology of childhood cancer. Cancer Treat Rev [Internet]. 2010 [cited 2018 mar 3]; 36(4):277-85. Available from: https:// www.researchgate.net/publication/41968708 Kaatsch_PEpidemiology_of_childhood_ cancer_Cancer_Treat_Rev_36_277-285.doi: 10.1016/j.ctrv.2010.02.003.

21 Blackburn GL, Thornton PA. Nutritional assessment of the hospitalized patient. Med. Clin. North Am. 1979;14:1102-8.

22 Lobato-Mendizábal E, López-Martínez B, Ruiz-Argüelles Gj. A critical review of the prognostic value of the nutritional status at diagnosis in the outcome of therapy of children with acute lymphoblastic leukemia. Rev Investig Clin [Internet]. 2003 [cited 2019 mar 4]; 31-5. Available from: http://www.pubfacts. com/detail/12708161/A-critical-review-ofthe-prognostic-value-of-the-nutritional-statusat-diagnosis-in-the-outcome-of- $t$

23 Loeffen EAH, Brinksma A, Miedema KGE, Bock GH, Tissing WJE. Clinical implications of malnutrition in childhood cancer patients-infections and mortality. Support Care Cancer 2015; 23(1):143-50. doi: 10.1007/s00520-0142350-9.

24 Brinksma A, Huizinga G, Sulkers E, Kamps $\mathrm{W}$, Roodbol P, Tissing W. Malnutrition in childhood cancer patients: a review on its prevalence and possible causes. Crit Rev Oncol Hematol [Internet]. 2012 [cited 2019 feb 4]; 83(2): 249-75. Available from: https:// pubmed.ncbi.nlm.nih.gov/22264939/. doi: 10.1016/j.critrevonc.2011.12.003. 
25 Tazi I, Hidane Z, Zafad S, Harif M, Benchekroun S, Ribeiro R. Nutritional status at diagnosis of children with malignancies in Casablanca. Pediatr Blood Cancer [Internet]. 2008 [cited 2018 feb 24]; 51(4):495-8. Available from: https://www.ncbi.nlm.nih.gov/pmc/articles/ PMC4684256/. doi: 10.1002/pbc.21689.

26 Garófolo A, Caran EM, Silva NS, Lopez FA. Prevalência de desnutrição em crianças com tumores sólidos. Rev Nutr [Internet]. 2005 [citado 2018 feb 24]; 18(2):193-200. Disponível em: https://www.scielo.br/ scielo.php?script $=$ sci_arttext\&pid $=$ S141552732005000200003\&lng=pt. doi: $10.1590 /$ S1415-52732005000200003.

27 Barr R, Collins L, Nayiager T, Doring N, Kennedy $\mathrm{C}$, Halton $\mathrm{J}$, et al. nutritional status at diagnosis in children with cancer. 2: An Assessment by Arm Anthropometry. J Pediatr Hematol Oncol [Internet]. 2011 [cited 2018 feb 24]; 33(3):101-4. Available from: https:// pubmed.ncbi.nlm.nih.gov/21368675/. doi: 10.1097/MPH.0b013e3182002a65.

28 Collins L, Nayiager T, Doring N, Kennedy $\mathrm{C}$, Webber $\mathrm{C}$, Halton $\mathrm{J}$, et al. Nutritional status at diagnosis in children with cancer I. An assessment by dietary recall--compared with body mass index and body composition measured by dual energy X-ray absorptiometry. J Pediatr Hematol Oncol [Internet]. 2010 [cited 2018 feb 24]; 32(8):e299-e303. Available from: https:/pubmed.ncbi.nlm.nih.gov/20962676/. doi: 10.1097/MPH.0b013e3181e9e43c.

29 Sala A, Rossi E, Antillon F, Molina, AL, Maselli T, Bonilla M, et al. Nutritional status at diagnosis is related to clinical outcomes in children and adolescents with cancer: a perspective from Central America. Eur J Cancer [Internet]. 2012 [cited 2019 mar 4]; 48(2):243-52. Available from: https://pubmed. ncbi.nlm.nih.gov/21737253/. doi: 10.1016/j. ejca.2011.06.006 